\title{
Novel RP-HPLC method for estimation of paracetamol and promethazine simultaneously in syrup formulation
}

\author{
Jasmine CHAUDHARY 1 * (D), Akash JAIN 1 (D), Vipin SAINI 2 (D) \\ 1 Faculty of Pharmaceutical Sciences, MM College of Pharmacy, MM (Deemed to be University), Mullana, Ambala- \\ 133207 Haryana, India. \\ 2 Maharishi Markandeshwar University, Kumarhatti, Solan-173229 Himachal Pradesh, India. \\ * Corresponding Author. jasmine.jain@mmumullana.org (J.C.); Tel. +91-805-993 0167.
}

Received: 04 October 2018/ Revised: 29 January 2019 / Accepted: 07 February 2019

ABSTRACT: Paracetamol with Promethazine $\mathrm{HCl}$ is most popular over the counter drug which is used as antipyretic and antiemetic. A novel, simple, precise, less time consuming, economical and accurate reverse phase HPLC method has been developed for their estimation using water, methanol and acetic acid in 79:20:1 v/v/v ratio as eluting phase on Kromasil Silica column keeping flow rate at $1 \mathrm{ml} / \mathrm{min}$ and detection at $249 \mathrm{~nm}$. Both drugs observed linearity between $10-50 \mu \mathrm{g} / \mathrm{ml}$ and successfully resolved within 6 minutes (3.565 and 5.641 minutes for paracetamol and promethazine respectively) with percent recovery between $98-101 \%$. Tailing factor is within the range and number of theoretical plates is more than 2500. Method was validated as per ICH guidelines and the results indicate that these drugs could be quantified simultaneously without excipient interference and thus suitable for routine analysis of drugs in combination.

KEYWORDS: Paracetamol; promethazine; HPLC; validation; simultaneous estimation.

\section{INTRODUCTION}

Paracetamol (PCM) (Figure 1a), a para-aminophenol derivative and chemically N-(4-hydroxyphenyl) acetamide is a white odourless crystalline powder, sparingly soluble in water. It is centrally and peripherally acting non-opioid analgesic having antipyretic and anti-inflammatory properties [1-8].

Promethazine (PMZ) (Figure 1b), a phenothiazine derivative and chemically N-(2'-dimethylamino-2'methyl) ethyl phenothiazine is white or faintly yellow crystalline powder, soluble in water and ethanol but insoluble in ether and acetone. It is $\mathrm{H}_{1}$ antagonist used as an antiemetic in motion sickness, an antipsychotic drug for treating mental disorders and also for enhancing analgesic, anesthetic and sedative effect of other medicines [19-20]. Various analytical methods like UV, HPLC etc. have been used for estimation for paracetamol [1-3, 5-18] and promethazine [19-27] individually or in combination with each other [28-30] as well as other drugs.<smiles>CC(=O)Nc1ccccc1</smiles>

Figure 1(a). Paracetamol<smiles>CC(CN1c2ccccc2Sc2ccccc21)N(C)C</smiles>

Figure 1(b). Promethazine

So the present study has been designed to develop a better cost effective, accurate, rapid and precise RP-HPLC method which can be used for the estimation of PCM and PMZ in combination.

How to cite this article: Chaudhary J, Jain A, Saini V. Novel RP-HPLC method for estimation of paracetamol and promethazine simultaneously in syrup formulation. J Res Pharm. 2019; 23(3): 476-483. 


\section{RESULTS AND DISCUSSION}

\subsection{Method development}

Both paracetamol and promethazine were satisfactorily resolved at $249 \mathrm{~nm}$ using mobile phase comprising of mixture of water, methanol and acetic acid (79: 20: $1 \% \mathrm{v} / \mathrm{v} / \mathrm{v}$ ) flowing at $1 \mathrm{ml} / \mathrm{min}$ on Kromasil Silica column $(250 \mathrm{~mm} \times 4.6 \mathrm{~mm}$, 5SL-II), with Prominence Diode Array Detector maintained at a temperature between $25-30^{\circ} \mathrm{C}$. Under optimized chromatographic parameters, the retention time of 3.565 min and 5.641 min was obtained for PCM and PMZ, respectively. Drug content as found was approximately $98 \%$ which shows accuracy of the method.

\subsection{Method validation}

The developed method was validated as prescribed by the ICH guidelines with respect to specificity, selectivity, system suitability, linearity, accuracy, robustness, precision [31-32].

\subsubsection{Specificity and selectivity}

Specificity and selectivity of the method was done to check for the interference of impurities. It was assessed by comparing the chromatograms obtained from mobile phase (blank), syrup solution with standard solution. No interfering peak was observed in chromatogram of blank (mobile phase) at retention time of both drugs. Moreover, the retention times of both drugs from standard as well as syrup solution were found almost identical, and no co-eluting peaks were observed, thus the method was specific as well as selective for quantitative estimation of both drugs in the commercial formulation [33].

\subsubsection{System suitability}

The system suitability parameters viz. retention time, peak area, resolution, theoretical plates and tailing factor) were calculated from the obtained chromatograms of the standard drugs. The obtained results are tabulated in Table 1 which are in acceptable criteria.

Table 1. System suitability parameters.

\begin{tabular}{lcc}
\hline Parameter & PCM & PMZ \\
\hline Linear Range $(\mu \mathrm{g} / \mathrm{ml})$ & $10.0-50.0$ & $10.0-50.0$ \\
Slope & $13553 \mathrm{x}$ & $15994 \mathrm{x}$ \\
Intercept & 20724 & 13349 \\
Regression coefficient $\left(\mathrm{r}^{2}\right)$ & 0.999 & 0.998 \\
Limit of Detection $(\mu \mathrm{g} / \mathrm{ml})$ & 1.2 & 0.51 \\
Limit of Quantitation $(\mu \mathrm{g} / \mathrm{ml})$ & 3.65 & 1.55 \\
Retention time $(\mathrm{min})$ & 3.565 & 5.641 \\
Tailing factor & 1.17 & 1.11 \\
Resolution factor & & 3.703 \\
Capacity factor & 0.237 & 0.456 \\
Theoretical plate & 27574.444 & 33077.879 \\
\hline
\end{tabular}

\subsubsection{Linearity}

Linearity was studied by plotting graph between peak area (Y-axis) and concentration (X-axis). Both the drugs were found to be linear in concentration range of 10.0-50.0 $\mu \mathrm{g} / \mathrm{ml}$ (Figure 2). Regression analysis was made for the slope $(\mathrm{m})$, intercept $(\mathrm{c})$ and coefficient of determination $\left(\mathrm{r}^{2}\right)$ as shown in Table I. Higher values of $\mathrm{r}^{2}$ indicate good linearity of the calibration curve for both the drugs. Sensitivity of the method was confirmed by low value of limit of detection (LOD) and limit of quantitation (LOQ) calculated using linear regression method. 


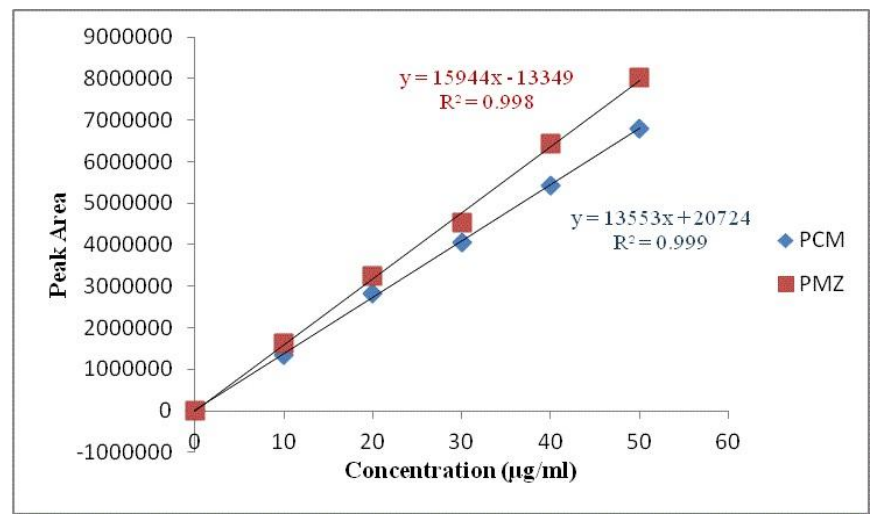

Figure 2. Linearity studies for PCM and PMZ at $249 \mathrm{~nm}$.

\subsubsection{Accuracy}

The accuracy of the developed method was evaluated by taking $80 \%, 100 \%, 120 \%$ of the sample solution and assessed by calculating \% RSD (Table 2). Recovery values greater than 98\% with \% RSD less than $2 \%$ indicated that these drugs could be quantified simultaneously and that there is no interference of the excipients present in the formulation which indicates that these drugs could be quantified simultaneously.

Table 2. Accuracy

\begin{tabular}{|c|c|c|c|c|c|c|c|c|}
\hline \multirow[t]{2}{*}{$\begin{array}{l}\text { Level of } \% \\
\text { recovery }\end{array}$} & \multicolumn{2}{|c|}{$\begin{array}{l}\text { Amount present } \\
(\mathrm{mg} / \mathrm{tab})\end{array}$} & \multicolumn{2}{|c|}{$\begin{array}{l}\text { Total amount } \\
\text { recovered (mg) }\end{array}$} & \multicolumn{2}{|c|}{$\%$ Mean Recovery \pm SD } & \multicolumn{2}{|c|}{ \% RSD } \\
\hline & PCM & PMZ & PCM & PMZ & PCM & PMZ & PCM & PMZ \\
\hline $80 \%$ & 100 & 40 & 97.78 & 39.38 & $97.78 \pm 0.13$ & $98.46 \pm 0.23$ & 0.132 & 0.23 \\
\hline $100 \%$ & 125 & 50 & 123.06 & 50.36 & $98.44 \pm 0.24$ & $100.73 \pm 0.16$ & 0.244 & 0.15 \\
\hline $120 \%$ & 150 & 60 & 146.57 & 59.6345 & $97.71 \pm 0.18$ & $99.39 \pm 0.35$ & 0.184 & 0.22 \\
\hline
\end{tabular}

\subsubsection{Precision}

\section{Repeatability (Intra-day precision)}

It was checked by analyzing sample solution three times on the same day. The results were found to be within the specified range (Table 3).

\section{Ruggedness (Interday precision)}

It was done by performing the same procedure by two different analysts on two different days. The results were found to be within the specified range (Table 3 ).

$\%$ RSD was found to be less than equal to 2 which indicate that the proposed method has good repeatability as well as reproducibility. 
Table 3. Precision studies

\begin{tabular}{|c|c|c|c|c|c|c|c|c|c|c|}
\hline & & & \multicolumn{8}{|c|}{ Inter day (RUGGEDNESS) } \\
\hline & & & \multicolumn{4}{|c|}{ DAY-I } & \multicolumn{4}{|c|}{ DAY-II } \\
\hline & \multicolumn{2}{|c|}{ Intra day } & $\begin{array}{c}\text { ANAL - } \\
\text { I }\end{array}$ & $\begin{array}{c}\text { ANAL } \\
\text {-II }\end{array}$ & $\begin{array}{c}\text { ANAL- } \\
\text { I }\end{array}$ & $\begin{array}{c}\text { ANAL - } \\
\text { II }\end{array}$ & $\begin{array}{c}\text { ANAL - } \\
\text { I }\end{array}$ & $\begin{array}{c}\text { ANAL - } \\
\text { II }\end{array}$ & $\begin{array}{c}\text { ANAL } \\
\text {-I }\end{array}$ & $\begin{array}{c}\text { ANAL- } \\
\text { II }\end{array}$ \\
\hline & PCM & PMZ & PC & $\mathbf{M}$ & PI & & PC & $\mathbf{M}$ & PN & $\mathbf{M Z}$ \\
\hline $\begin{array}{l}\text { Amount } \\
\text { Found } \\
\text { (mg) }\end{array}$ & 122.96 & 4.917 & 125.5 & 123.85 & 5.03 & 4.906 & 125.15 & 125.77 & 5.031 & 4.91 \\
\hline $\begin{array}{c}\% \\
\text { Amount } \\
\text { found }\end{array}$ & $\begin{array}{c}98.37 \\
\%\end{array}$ & $98.34 \%$ & 100.4 & 99.08 & 100.06 & 98.12 & 101.72 & 100.61 & 100.62 & 98.20 \\
\hline $\begin{array}{c}\text { Mean \% } \\
\pm \text { S.D }\end{array}$ & $\begin{array}{l}98.37 \% \\
\pm 0.117\end{array}$ & $\begin{array}{l}98.34 \% \\
\pm 0.002\end{array}$ & $99.74=$ & 0.933 & 99.09 & 1.371 & 101.16 & \pm 0.784 & $99.41 \pm$ & 1.711 \\
\hline $\begin{array}{c}\text { Precision, } \\
\% \text { RSD }\end{array}$ & 0.095 & 0.556 & 0.9 & & & & & 75 & 1.7 & 21 \\
\hline
\end{tabular}

\subsubsection{Robustness}

No marked change was observed on slightly modifying the chromatographic parameters like wavelength, flow rate, temperature etc. which indicates the robustness of developed method. Results are indicated in Table 4.

Table 4. Robustness studies

\begin{tabular}{cccccc}
\hline \multirow{2}{*}{ Method Parameter } & \multirow{2}{*}{ Level } & \multicolumn{2}{c}{ Retention Time } & \multicolumn{2}{c}{ Tailing factor } \\
\cline { 3 - 6 } & \multicolumn{7}{c}{ PCM } & \multicolumn{2}{c}{ PMZ } & PCM & PMZ \\
\hline \multicolumn{7}{c}{ Wavelength } \\
\hline $\mathbf{2 4 9}$ & -1 & 3.558 & 5.369 & 1.157 & 1.758 \\
$\mathbf{2 5 0}$ & 0 & 3.558 & 5.447 & 1.163 & 1.789 \\
$\mathbf{2 5 1}$ & +1 & 3.559 & 5.359 & 1.16 & 1.756 \\
& \multicolumn{7}{c}{ Flow Rate (mL/min) } & & \\
\hline $\mathbf{0 . 8}$ & -0.2 & 3.957 & 5.971 & 1.789 & 1.789 \\
$\mathbf{1 . 0}$ & 0 & 3.558 & 5.447 & 1.163 & 1.789 \\
$\mathbf{1 . 2}$ & +0.2 & 3.225 & 4.876 & 1.164 & 1.765 \\
& \multicolumn{7}{c}{ Temperature (oC) } & & \\
\hline $\mathbf{2 0}$ & -5 & 3.467 & 5.561 & 1.123 & 1.772 \\
$\mathbf{2 5}$ & 0 & 3.558 & 5.447 & 1.163 & 1.789 \\
$\mathbf{3 0}$ & +5 & 3.523 & $5 . .654$ & 1.145 & 1.758 \\
\hline
\end{tabular}

\subsubsection{Content uniformity (Assay)}

The commercially available syrup was analyzed using developed method and the drug content was found to be $98.38 \% \pm 0.863$ and $98.31 \% \pm 0.117$ for PCM and PMZ respectively (Table 5).

Table 5. Assay Results for Syrup Formulation

\begin{tabular}{|c|c|c|c|c|c|c|}
\hline \multirow[b]{2}{*}{ Drug } & \multirow[b]{2}{*}{ Label Claim } & \multicolumn{2}{|c|}{ Peak area } & \multirow{2}{*}{$\begin{array}{l}\text { Amount } \\
\text { found } \\
(\mathrm{mg})\end{array}$} & \multirow{2}{*}{$\begin{array}{l}\% \text { drug found } \\
\pm \text { SD }\end{array}$} & \multirow[t]{2}{*}{ \%RSD } \\
\hline & & Standard & Sample & & & \\
\hline PCM & $125 \mathrm{mg} / 5 \mathrm{ml}$ & 29583707 & 29564277 & 122.97 & $98.37 \pm 0.108$ & 0.087 \\
\hline PMZ & $5 \mathrm{mg} / \mathrm{ml}$ & 2647377 & 2583984 & 4.91 & $98.3 \pm 0.005$ & 0.118 \\
\hline
\end{tabular}

\section{CONCLUSION}

The developed isocratic RP-HPLC method has been found economic, simple, rapid, accurate, and precise which can be routinely used for simultaneous estimation of PCM and PMZ in syrup formulation without the interference of excipients. All the parameters viz. accuracy, specificity, robustness, precision 
were in acceptance criteria as per ICH guidelines with retention time less than 6 minutes for both the drugs. The developed method was also found to be better and precise than the reported methods in terms of better accuracy, more efficiency as indicated by high number of theoretical plates, low tailing factor, and simple readily available column has been used.

\section{MATERIALS AND METHODS}

\subsection{Materials}

Pure samples of Paracetamol and Promethazine were obtained as gift samples. Syrup formulation containing PCM $125.0 \mathrm{mg} / 5 \mathrm{ml}$ and PMZ HCl $5.0 \mathrm{mg} / \mathrm{ml}$ was procured from the local market. HPLC grade methanol, water and acetic acid were purchased from SD Fine Chemicals Ltd., India which were used after filtration under vacuum from 0.45 membrane filter.

\subsection{Instrumentation}

Chromatographic separation was performed on Shimadzu LC- 20 AT HPLC (Double pump) with Rheodyne $7725 \mathrm{i}$ type injector (20 $\mu 1$ loop capacity), Kromasil Silica column $(250 \mathrm{~mm} \times 4.6 \mathrm{~mm}$, 5SL-II), SPD M20A, Prominence Diode Array Detector. Various mobile phases were tried from which mobile phase comprising of mixture of water, methanol and acetic acid (79:20:1\% v/v/v) flowing at $1 \mathrm{ml} / \mathrm{min}$ was found to be most suitable. Mobile phase was filtered ( 0.45 membrane filter) under vacuum and degassed in ultrasonic bath for 30 minutes before passing through the instrument. Chromatographic separations were carried out at room temperature $\left(25-30^{\circ} \mathrm{C}\right)$ with detection at $249 \mathrm{~nm}$.

\subsection{Method}

\subsubsection{Preparation of standard solution}

Pure promethazine $(50 \mathrm{mg})$ was dissolved in methanol $(50 \mathrm{ml})$ to get standard solution $(1000 \mu \mathrm{g} / \mathrm{ml})$. $5 \mathrm{ml}$ of this solution was added to another solution prepared by dissolving pure paracetamol $(125 \mathrm{mg})$ in $50 \mathrm{ml}$ methanol to get solution of $100 \mu \mathrm{g} / \mathrm{ml}$ and $500 \mu \mathrm{g} / \mathrm{ml}$ of Promethazine and Paracetamol respectively. The resulting solution after filtration $(5.0 \mu \mathrm{l})$ was injected into the chromatographic system and the chromatogram was recorded (Figure. 3).

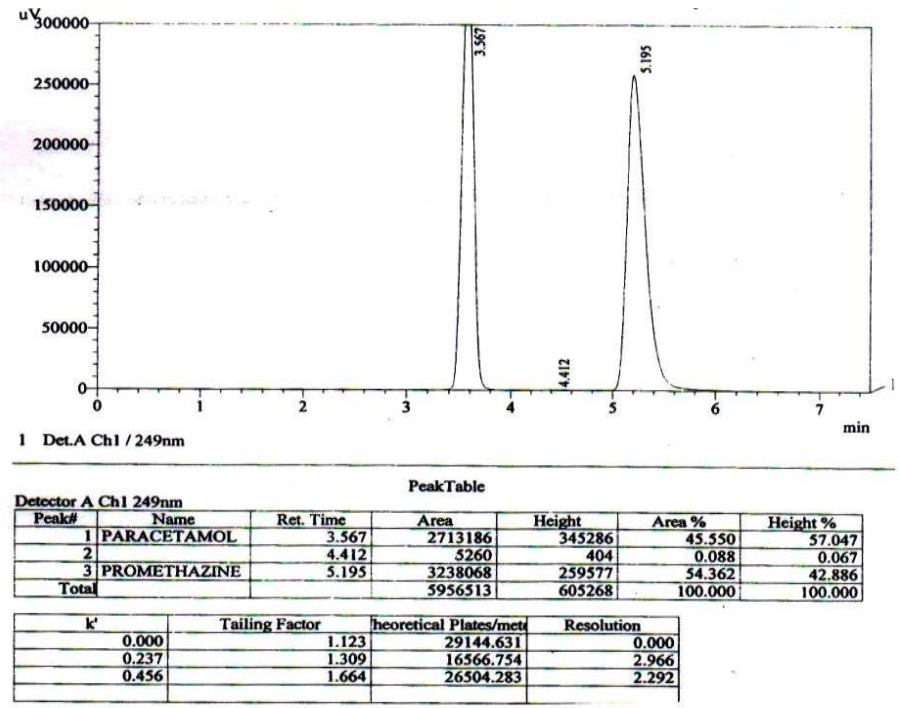

Figure 3. Chromatogram for standard paracetamol and promethazine.

\subsubsection{Preparation of calibration curve}

Appropriate aliquots were pipetted out from the standard stock solution to get set of solutions having the concentration range, ranging from $10.0-50.0 \mu \mathrm{g} / \mathrm{ml}$ of each drug. These solutions $(5 \mu \mathrm{l})$ were chromatographed and the peak areas were measured. Peak areas were then plotted against the respective concentrations for both the drugs (Fig. 2). From the plots the linear range for both PCM and PMZ was found to be between $10.0-50.0 \mu \mathrm{g} / \mathrm{ml}$. 


\subsubsection{Preparation of sample solution}

Syrup formulation labeled 125mg/5ml PCM and 5mg/ml PMZ was added to 50ml of HPLC grade methanol. The resulting solution $(500.0 \mu \mathrm{g} / \mathrm{ml}$ and $100.0 \mu \mathrm{g} / \mathrm{ml}$ of PCM and PMZ respectively) after filtration was injected into the chromatographic system and the chromatogram was recorded (Figure. 4). Results of the analysis are shown in Table 5.

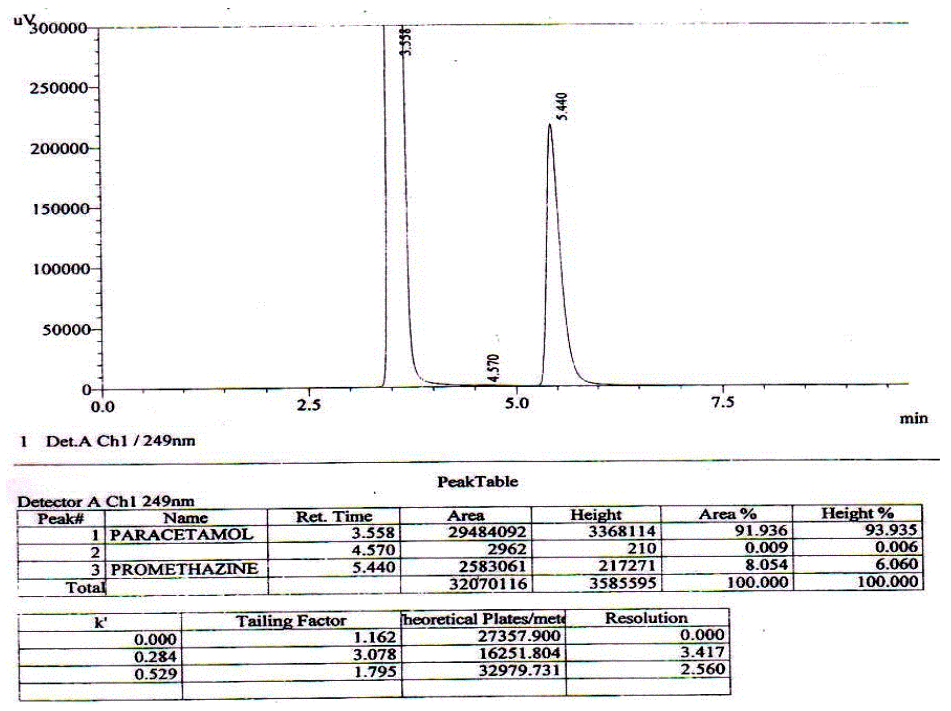

Figure 4. Chromatogram of syrup formulation.

Acknowledgement: We also wish to express our gratitude to management of M.M. (Deemed to be University), Mullana, Ambala for providing necessary facilities for carrying out the work.

Author contribution: Concept- V.S., J.C.; Design- V.S., J.C.; Supervision- V.S.; Data Collection and Processing- J.C.; Analysis/Interpretation- J.C., A..J; Literature Search- J.C., A.J.; Writing- J.C., A..J; Critical Reviews- V.S., J.C., A.J.

Conflict of interest statement: The authors declared no conflict of interest

\section{REFERENCES}

[1] Arayne MS, Sultanab N, Siddiquia FA. Simultaneous determination of paracetamol and orphenadrine citrate in dosage formulations and in human serum by RP-HPLC. J Chin Chem Soc. 2009; 56: 169-174. [CrossRef]

[2] Mahaparale S, Telekone RS, Raut RP, Damle SS, Kasture PV. Simultaneous spectrophotometric determination of drotaverine hydrochloride and paracetamol in tablet. Indian J Pharm Sci. 2010; 72(1): 133-136. [CrossRef]

[3] Kapil K, Naik S, Garima J, Mishra N. Spectrophotometric method for simultaneous estimation of paracetamol and domperidone in tablet formulation. Asian J Chem. 2009; 2(2): 50-54.

[4] Baheti KG, Shaikh S, Shah N, Dehgan MH. Validated simultaneous estimation of paracetamol and etoricoxib in bulk and tablet by HPTLC method. Inter J Res Pharma Biomed Sci. 2011; 2(2): 672-675.

[5] Pattan SR, Jamdar SG, Godgel RK, Dighel NS, Daithankar AV, Nirmal SA, Pai MG. RP- HPLC method for simultaneous estimation of paracetamol and etoricoxib from bulk and tablets. J Chem Pharm Res. 2009; 1(1): 329335.

[6] Battu PR, Ready MS. RP-HPLC method for simultaneous estimation of paracetamol and ibuprofen in tablets. Asian J Res Chem. 2009; 2(1): 70-72.

[7] Issa YM, Zayed SIM, Habib IHI. Simultaneous determination of ibuprofen and paracetamol using derivatives of the ratio spectra method. Arab J Chem. 2011; 4(3): 259-263. [CrossRef]

[8] Kirtawade R, Salve P, Seervi C, Kulkarni A, Dhabale P. Simultaneous UV spectrophotometric method for estimation of paracetamol and nimesulide in tablet dosage form. Int J Chemtech Res. 2010; 2(2): 818-821.

[9] Behera S, Ghanty S, Ahmad F, Santra S, Banerjee S. UV-Visible spectrophotometric method development and validation of assay of paracetamol tablet formulation. J Anal Bioanal Tech. 2012; 3(6): 151-156. [CrossRef] 
[10] Nagendra P. Spectrophotometric estimation of paracetamol in bulk and pharmaceutical formulations. EJ Chem. 2011; 8(1): 149-152. [CrossRef]

[11] Giriraj P, Sivakkumar T. New simple spectrophotometric method for the simultaneous estimation of paracetamol and flupirtine maleate in pure and pharmaceutical dosage form. Int J Spectrosc. 2014: 1-6. [CrossRef]

[12] Oza CK, Nijhawan R, Pandya MK, Vyas AJ, Patel AI. Q-Analysis spectrophotometric method for the simultaneous determination of nabumetone and paracetamol in API and in tablet dosage form. Asian J Pharm Anal. 2013; 3(1): 916.

[13] Rote AR, Kumbhoje PA and Bhambar RS. UV-visible spectrophotometric simultaneous estimation of paracetamol and nabumetone by AUC method in combined tablet dosage form. Pharm Method. 2012; 3(1): 40-43.[CrossRef]

[14] Likhar AD, Gupta KR and Wadodkar SG. Spectrophotometric methods for the simultaneous estimation of paracetamol and etoricoxib in tablet dosage forms. Int J Pharm Pharm Sci. 2010; 2(1): 156-161.

[15] Thippeswamy M, Somanna P, Krishnan P, Bhandare B, Sahajanand H. A new method development and validation for estimation of paracetamol in pharmaceutical dosage form by reverse phase-high performance liquid chromatography. Int J Pharm Pharm Sci. 2015; 7(8): 190-194.

[16] Devi TA, Setti A, Srikanth S, Nallapeta S, Pawar SC, Rao JV. Method development and validation of paracetamol drug by RP-HPLC. J Med Allied Sci. 2013; 3(1): 8-14.

[17] Maslarska VN, Tsvetkova BG and Peikova LP. RP-HPLC method for simultaneous determination of paracetamol, diclofenac sodium and famotidine in tablet dosage form. Int J Pharm Res Scholars. 2015; 4(2): 55-61.

[18] Chandra R, Verma D, Sharma KD, Kumar S, Alam N, Singh S. Comparative quantitative determination of paracetamol by RP-HPLC and UV-spectrophotometry from its formulated tablets. Int J Pharm Pharm Sci. 2013; 5(3): 863-865.

[19] Vanapalli SR, Kambhampatil SP, Putcha L, Bourne DWA. A liquid chromatographic method for the simultaneous determination of promethazine and three of its metabolites in plasma using electrochemical and UV detectors. J Chromatogr Sci. 2001; 39: 170-172. [CrossRef]

[20] Xiao P, Wu W, Yu J, Zhao F. Voltammetric sensing of promethazine on a multi-walled carbon nanotubes coated gold electrode. Int J Electrochem Sci. 2007; 2: 149-157.

[21] Lin SX and Huo CG. Determination of promethazine hydrochloride in promethazine hydrochloride syrup by HPLC. Chin J Mod Appl Pharm. 2008: 03.

[22] Nurahmanto D. Development and validation of UV spectrophotometric method for quantitative estimation of Promethazine $\mathrm{HCl}$ in phosphate buffer saline pH 7.4. Int Curr Pharm J. 2013; 2(8): 141-142. [CrossRef]

[23] Khaleda HS and Rana AH. Spectrophotometric determination of promethazine hydrochloride and paracetamol in pharmaceutical tablets. J Al-Nahrain Univ. 2014; 17(1): 14-23.

[24] Sharma A, Upadhyay N, Sapra S, Dhar KL, Sharma M. Method development and validation for simultaneous estimation of promethazine hydrochloride and pholcodine in bulk and marketed formulation (Linctus) by UV spectrophotometery. Develop Drugs. 2013; 2(4): 73. [CrossRef]

[25] Balammal G, Sagari NSM, Kumar BSM and Reddy PJ. Spectrophotometric estimation of promethazine hydrochloride in bulk and pharmaceutical formulation. Int J Pharm Res Anal. 2012; 2(16): 6-8.

[26] Qader HA and Fakhre NA. Spectrophotometric determination of promethazine hydrochloride in pure and pharmaceutical dosage forms. ZJPAS. 2017; 29: s107-s114.

[27] Al-kahdimy AS. Flame emission and molecular absorption spectrophotometric determination of promethazine hydrochloride via potassium dichromate as oxidant reagent. World J Pharm Sci. 2016; 4(3): 323-329.

[28] Sawant RL, Ahmed R, Supriya RS, Sheetal DR. Spectrophotometric estimation of paracetamol and promethazine in tablet dosage forms. Der Pharma Chemica. 2012; 4(2): 714-719.

[29] Borkar DD, Godse VP, Bafana YS, Bhosale AV. Simultaneous estimation of paracetamol and promethazine hydrochloride in pharmaceutical formulations by RP-HPLC method. Int J Chemtech Res. 2009; 1(3): 667-670.

[30] Kakadiya J, Parmar N, Shah N. Development and validation of RP-HPLC method for simultaneous estimation of promethazine hydrochloride and paracetamol in combined liquid formulation. Asian J Res in Biol Pharm Sci . 2014; 2(1): 11-26.

[31] International Conference on Harmonization Q1B, Stability testing: Photostability testing of new drug substances and products, International Conference on Harmonization, Geneva, 1996. 
https://www.ich.org/fileadmin/Public_Web_Site/ICH_Products/Guidelines/Quality/Q1B/Step4/Q1B_Guideli ne.pdf

[32] International Conference on Harmonization, ICH Guidelines, Validation of analytical procedures technical requirements for registration of pharmaceuticals for human use: Text and Methodology Q2(R1), International Conference on Harmonization, Geneva, Switzerland, November 2005. http://www.gmpcompliance.org/guidemgr/files/Q2(R1).PDF

[33] Yenduri G, Navuluri S. Analytical high performance liquid chromatography method for estimating the combination of aspirin and omeprazole in bulk and tablet dosage form. Marmara Pharm J. 2018; 22 (4): $502-510$. [CrossRef]

This is an open access article which is publicly available on our journal's website under Institutional Repository at http://dspace.marmara.edu.tr 